\title{
Drying Characteristics of Bael Fruit (Aegle marmelos) Pulp in Mechanical Tray Dryer
}

\author{
Ankita Sharma ${ }^{1 *}$, S Champawat ${ }^{2}$, Surbhi Suman ${ }^{3}$, \\ Kusum Meghwal ${ }^{2}$ and Neha Prajapat ${ }^{2}$ \\ ${ }^{1} J N K V V$, Jabalpur, India \\ ${ }^{2}$ CTAE, MPUAT, Udaipur, India \\ ${ }^{3}$ Career Point University, Kota, India \\ *Corresponding author
}

\begin{abstract}
A B S T R A C T
Bael or Aegle marmelos is a spiritual, religious and medicinal plant. The pulp of the bael fruit contains many functional and bioactive compounds such as carotenoids, phenolics, alkaloids, coumarins, flavonoids, terpenoids and other antioxidants which may protect against chronic diseases. The pulp of bael fruit was extracted. The crude mass, containing seed, pulp and fibre was added with water having equal quantity, mixed and heated for 1 min at $80^{\circ} \mathrm{C}$. $\mathrm{pH}$ was maintained with the help of citric acid solution. The mixture was passed through 20 mesh sieves to separate out the seeds to obtain pulp for drying purpose. Bael fruit pulp were dried in tray dryer at three drying temperatures viz. 55,60 and $65^{\circ} \mathrm{C}$ and four thickness of pulp on the tray $(2,4,6$ and $8 \mathrm{~mm})$. The initial moisture content of sample was in the range of 74.49 per cent to 77.10 per cent (wb). Final moisture content ranges in between $6.86-9.96$ per cent $(w b)$ for dried bael fruit pulp. Maximum Average drying time was found at temperature $55^{\circ} \mathrm{C}(8 \mathrm{~mm})$ of about $1020 \mathrm{~min}$ and minimum at $65^{\circ} \mathrm{C}(2 \mathrm{~mm})$ was $480 \mathrm{~min}$. Moisture reduction per hour was higher at initial stages and then started to decrease with drying time. It was observed that drying occurred completely in falling rate period and no constant rate period was observed at all drying temperatures. The moisture diffusivity varied in the range of $1.21 \times 10^{-9} \mathrm{~m}^{2} / \mathrm{s}$ to $5.84 \times 10^{-8} \mathrm{~m}^{2} / \mathrm{s}$ during drying.
\end{abstract}

\section{Introduction}

Bael (Aegle marmelos) is an indigenous fruit of India belongs to family Rutaceae and it is commonly known as Bengal quince (John and Stevenson, 1979), Bilva, Indian quince, Golden apple, Holy fruit, Bel,Sriphal, Stone apple and Maredo in India. It has tolerance to arid conditions (Chundawat, 1990) as well as high rainfall. The Bael tree has its origin from
Eastern Ghats and central India. Bael fruit is a sub-tropical, deciduous tree and fruit is globuse with grey or yellowish hard woody shell. Inside this, there is soft yellow or orange coloured mucilaginous pulp with numerous seeds. It has numerous seeds, which are densely covered with fibrous hairs and are embedded in a thick, gluey and aromatic pulp (Kaushik et al., 2008). 
The production of bael in India is 0.08583 MT in 2015-16 (Anonymous, 2015) from some major production state i.e. Uttar Pradesh, Jharkhand, Uttaranchal, Orissa, Rajasthan, Madhya Pradesh, Chhattisgarh etc.

The pulp of fruit contains many functional and bioactive compounds such as carotenoids, phenolics, alkaloids, coumarins, flavonoids, terpenoids, and other antioxidants which may protect against chronic diseases (Anonymous 2012). The flavour is sweet, aromatic and pleasant, although tangy and slightly astringent in some varieties. It resembles a marmalade made, in part with citrus and in part with tamarind. Numerous hairy seeds are encapsulated in a slimy mucilage (Kundu et al., 2014)

Bael (Aegle marmelos)is one of the most important minor fruit crops with medicinal and antioxidant properties grown in India from sea level to moderately high altitude. Fruit development stages (FDS) are associated with significant changes in carbohydrates, sugars and poly-phenol content. Bael contains appreciable amount of minerals like $\mathrm{Ca}, \mathrm{Mg}$, Fe and other elements which are very important for human health.

Bael powder can be stored for long time, if harvested at 4-8 months after fruit set (Kaur and Kalia, 2017). It is useful in the treatment of diabetic patients due to high contents of mucilage and secondary metabolites as coumarin and mamelosin (Prajapat et al., 2012). Bael is also effective against cancer, cardiovascular diseases and ulcer. (Maity et al., 2009)

Number of fruits, vegetables and medicinal plants are dried for their uses in the foods and medicines. The pulp of bael fruit contains many functional and bioactive compounds. Drying is a traditional process applied to food dewatering. If this pulp is dried to make powder then it will be useful in curing many diseases. Dried products and industrial applications require appropriate manufacturing procedures at the industrial level. No systematic methodology is reported so far made for getting a dried product from bael fruit. Therefore, the present study focuses to investigate the drying behaviour of bael fruit pulp and investigate a suitable drying.

\section{Materials and Methods}

The present investigation for developing the bael fruit pulp powder was carried out in the Department of Processing and Food Engineering, College of Technology and Engineering, Maharana Pratap University of Agriculture and Technology, Udaipur, Rajasthan. The various methods are used to predict various dependent variables such as drying time, drying rate, colour, water activity and ascorbic acid and finally the methodology used for quality evaluation of bael fruit pulp powder is also presented.

\section{Fruit}

The fruit may be round, oval, or oblong, 2 to 8 in $(5-20 \mathrm{~cm})$ in diameter, may have a thin, hard, woody shell or a more or less soft rind, gray-green until the fruit is fully ripe, when it turns yellowish. It is dotted with aromatic, minute oil glands.

Inside, there is a hard-central core and 8 to 20 faintly defined triangular segments, with thin, dark-orange walls, filled with aromatic, paleorange, pasty, sweet, resinous, more or less astringent, pulp. Embedded in the pulp are 10 to 15 seeds, flattened-oblong, about $3 / 8$ in (1 $\mathrm{cm})$ long, bearing woolly hairs and each enclosed in a sac of adhesive, transparent mucilage that solidifies on drying. (Julia and Miami, 1987). 


\section{Raw Materials}

Bael fruit (NB-5) will be used for this investigation. It will be procured from nearest local market of Udaipur. Decayed fruit were discarded.

\section{Sample preparation}

The fruit pulp was extracted according to the method adopted by Roy and Singh (1979). The crude mass (pulp + seeds + fibre) was added with equal quantity of water, mixed and heated for $1 \mathrm{~min}$ at $80^{\circ} \mathrm{C}$ while maintaining the $\mathrm{pH} 4.3$ with the help of citric acid solution. The mixture was passed through 20 mesh sieves to obtain pulp for drying purpose.

\section{Drying of bael fruit pulp}

Before drying experiments, initial moisture content of the examples was determined. The initial moisture content of bael fruit pulp was $359.98 \%(\mathrm{db})$ and final moisture content of the finished product was about $30 \%$ (db). Three air-drying temperatures $(55,60$ and $65^{\circ} \mathrm{C}$ ) and four thickness of pulp on the tray (2, 4, 6 and $8 \mathrm{~mm}$ ) were chosen to obtain the drying characteristics of bael fruit pulp. After the dryer reached at steady-state conditions for the set points (for $1 \mathrm{~h}$ ), the pulp was distributed uniformly into the tray in all four thicknesses. Moisture loss was recorded at every $5 \mathrm{~min}$ interval for $20 \mathrm{~min}, 10 \mathrm{~min}$ interval for $80 \mathrm{~min}, 15 \mathrm{~min}$ interval for 60 min, 20 min interval for next $80 \mathrm{~min}$ and after that $1 \mathrm{hr}$ interval until the constant weight was achieved. For measuring the weight of the sample during experimentation, the tray with sample was taken out of the drying chamber, weighed on the digital top pan balance and placed back into the chamber (within $15 \mathrm{~s}$ ). The digital top pan balance was kept very close to the drying unit. Drying was continued until the moisture content of sample reached about $30-40 \%$ (db). The replications of experiments were taken. The dried samples were cooled at normal room temperature (25 $\pm 2^{\circ} \mathrm{C}$ ) and packed in polyethylene bags and sealed.

The process flow chart used for development of bael fruit pulp powder is presented in Fig 1.

\section{Measurement of Initial Moisture Content}

The moisture content of the fresh bael fruit pulp was determined before drying by using hot air oven method. (AOAC, 2000)

Moisture content $(\mathrm{wb} \%)=\frac{\frac{W_{1}-w_{x}}{W_{1}}}{10} \times 100$

Where,

$\mathrm{W} 1$ = mass of original sample $(\mathrm{g}), \mathrm{W} 2=$ mass of the sample after drying $(\mathrm{g})$

\section{Drying Characteristics}

\section{Moisture content}

The reduction in moisture content of bael fruit pulp was recorded at an interval of $5 \mathrm{~min}$ for first $20 \mathrm{~min}$, then at an interval of $10 \mathrm{~min}$ for next $80 \mathrm{~min}$, then $15 \mathrm{~min}$ for next $60 \mathrm{~min}, 20$ min for another $80 \mathrm{~min}$ and afterwards $60 \mathrm{~min}$ interval till the end of drying process.

Moisture Content $(\mathrm{db})=\frac{\mathrm{W}_{\mathrm{e}}-\mathrm{DM}}{\mathrm{DM}} \times 100$

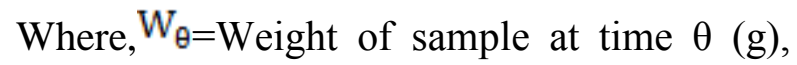
$\mathrm{DM}=$ Dry matter of the sample $(\mathrm{g})$

\section{Drying rate}

The moisture content data recorded during experiments were analysed to determine the moisture lost from the samples in particular time interval. The drying rate of sample was 
calculated by following mass balance equation (Brooker et al., 1974).

$$
R=\frac{W M L(\mathrm{~kg})}{\text { Time interval }(\mathrm{min}) \times D M(g)}
$$

Where, $\mathrm{R}=$ Drying rate at time $\theta, \mathrm{g}$ water/ g.min, WML=Initial weight of sample Weight of sample after time $\theta$

\section{Moisture ratio}

The moisture ratio was calculated by using the following equation:

Moisture ratio $=\frac{M-M_{\theta}}{M_{0}-}$

Where,

$\mathrm{M}=$ Moisture content at any specified time $\mathrm{t}$ (per cent $\mathrm{db}$ )

$\mathrm{Me}=$ Equilibrium moisture content (per cent $\mathrm{db})$

$\mathrm{M}_{0}=$ Initial moisture content (per cent $\mathrm{db}$ )

$M_{e}$ in comparison to $M_{0}$ and $M$ is very small, hence $\mathrm{M}_{\mathrm{e}}$ can be neglected and moisture ratio can be presented in simplified form (Doymaz, 2004; Goyal et al., 2007).

$M R=\frac{M}{M_{0}}$

\section{Results and Discussion}

Moisture loss of pulp as a function of drying time was very similar for all drying temperatures and drying thickness. In the starting of drying process, decrease in moisture content was faster, which is evident due to availability of high moisture initially. At initial stages moisture depletion per hour was higher and then started to decrease with drying time. These results are in good agreement with the earlier studies Meisamiasl and Rafiee (2009) for apple drying and
Kumar et al., (2011) for carrot pomace drying.

The moisture content of bael fruit pulp decreased exponentially with drying time under all drying conditions. The drying followed a typical trend of drying behavior for food materials as reported earlier by Singh, (2001). As the drying air temperature increased, the drying curves exhibited steeper slope indicating that the drying rate increased with increase in drying air temperature. This resulted into substantial decrease of drying time.

It can further be observed that the moisture content decreased at a faster rate for the samples having lesser thickness, which may be due to increase in thickness of inner layers of pulp resulting in lower moisture removal. It can be noted from Figure 2, 3, 4 and 5 that the drying times to reach the final moisture content for the fresh bael pulp sample were $300-780,360-840,400-960$ and $480-$ 1080 at temperatures of $55-65^{\circ} \mathrm{C}$ for various thickness of 2, 4, 6 and $8 \mathrm{~mm}$ respectively. Obviously, within a certain temperature range $\left(55-65^{\circ} \mathrm{C}\right)$, increasing drying temperature speeds up the drying process, thus shortens the drying time. Similar findings have been reported for fruit and vegetable products drying (Vergara et al., 1997; Fenton and Kennedy, 1998; Ramaswamy, 2002; Wang et al., 2007).

The drying time increased with the increase in thickness of drying layer, which is evident due to less exposed area available for evaporation per unit mass of pulp. The initial moisture content of sample $2 \mathrm{~mm}$ after mixing water in raw pulp, citric acid was also added to maintaining the ph 4.5 and thin layer drying of $7 \mathrm{~h}$ was in the range of 74.49 to 76.59 (per cent, wb) and after drying up to (nearly) constant weight, the moisture content was reduced in the range of 6 to 10 per cent (wb) for different drying air temperatures. 
The typical curves showing variation in moisture content with drying time of dried pulp for different air temperature.

The initial moisture content of sample having $2 \mathrm{~mm}$ layer thickness was in the range of 314.17 per cent to 327.08 per cent (db). It can be seen from Fig2; it took nearly 780 min of drying to reduce the moisture content from 314.17 per cent to 10.04 per cent $(\mathrm{db})$ when drying air temperature was $55^{\circ} \mathrm{C}$.

\section{Effect of temperature on drying rate curves of bael fruit pulp}

The drying rate for the bael fruit pulp was estimated from the difference in its moisture weight in a known time interval and expressed as $\mathrm{g}$ of moisture evaporated per $\mathrm{g}$ of dry matter-min. The drying rate as a function of moisture content at different drying air temperature for bael fruit pulp with treatment in tray dryer is shown in Fig. 6 to 9. It can be seen that initially the drying rate was more and subsequently it reduced with drying time. It can also be seen that they follow typical drying rate curves. The maximum drying rate for $2 \mathrm{~mm}$ layer thickness sample was observed at initial stage of drying 4.583, 4.192 and 3.401 g-water/ gdry matter-min, for $4 \mathrm{~mm}$ layer thickness sample 4.781, 3.964 and 3.365 g-water/ g-dry matter-min, for $6 \mathrm{~mm}$ layer thickness 3.393, 2.703 and 2.174 gwater/ g-dry matter-min and for $8 \mathrm{~mm}$ layer thickness $2.045,1.840$ and $1.584 \mathrm{~g}$-water/ gdry matter-min at 65,60 and $55^{\circ} \mathrm{C}$ of drying air temperature respectively. These drying rates continuously decreased with respect to time.

From the observation it can be seen that a constant rate-drying period was not found in drying curves. The entire drying process took place in the falling rate period; the curves typically demonstrated smooth diffusion controlled drying behaviour under all drying temperatures. Moreover, an important influence of air-drying temperature on drying rate could be observed in these curves. It is obvious from these curves that the drying rate was decreased with the increase in thickness and increased with the increase in temperature, so the highest values of drying rate were obtained during the experiment at $65^{\circ} \mathrm{C}$ and $2 \mathrm{~mm}$ thickness. These results are similar to the earlier studies outcomes of different vegetables (Akpinar, 2003; Doymaz et al., 2010; Doymaz et al., 2011).

A second order polynomial relationship was found to have fitted adequately to desirable variations in the drying rates with moisture content at all three experimental temperatures and is represented by equation 1 :

$\mathrm{Y}=\mathrm{Ax} \mathrm{x}^{2}+\mathrm{Bx}+\mathrm{C}$ 1

Where, $\mathrm{Y}$ is the rate of drying in $\mathrm{g}$ water evaporated per $g$ dry matter-min. A, B and C are constants and $\mathrm{x}$ are the moisture content in $\mathrm{g}$ water per $\mathrm{g}$ of dry matter. It is also seen that the values of coefficient of correlation are more than 0.90 at all the process temperatures which shows the good correlation among the predicted and observed values.

Similar trend was also reported by various research workers for different food products such as for papaya by (Jain et al., 2011).

\section{Effect of temperature on moisture diffusivity}

The moisture loss data from convective drying were analyzed and moisture ratios at various time intervals were determined. The ln (MR) was plotted with drying time in order to find out moisture diffusivity. The variation in $\ln$ (MR) with drying time has been presented in Fig. 10 to 13 for tray drying. The variation in $\ln (\mathrm{MR})$ with drying time for each case was found to be linear with inverse 
slope. The slope became steeper with increase in temperature level. Moisture diffusivities were calculated and from the slopes of these straight lines (Maskan et al., 2002; Doymaz, 2004; Kadam et al., 2011).

Table.1 Drying rate equation with respect to moisture content (\% db)

\begin{tabular}{|c|c|c|c|}
\hline Treatment & Temperature $\left({ }^{\circ} \mathbf{C}\right)$ & Equation & $\mathbf{R}^{2}$ \\
\hline \multirow{3}{*}{$\mathbf{6 5}^{\circ} \mathbf{C}$} & 2 & $\mathrm{y}=0.00004 \mathrm{x}^{2}+0.003 \mathrm{x}+0.041$ & 0.987 \\
\cline { 2 - 4 } & 4 & $\mathrm{y}=0.511 \mathrm{x}^{2}-0.243 \mathrm{x}+0.294$ & 0.945 \\
\cline { 2 - 4 } & 6 & $\mathrm{y}=0.280 \mathrm{x}^{2}-0.043 \mathrm{x}+0.181$ & 0.937 \\
\hline \multirow{3}{*}{$\mathbf{6 0}^{\circ} \mathbf{C}$} & 8 & $\mathrm{y}=0.092 \mathrm{x}^{2}+0.272 \mathrm{x}+0.079$ & 0.962 \\
\hline & 2 & $\mathrm{y}=0.00006 \mathrm{x}^{2}-0.005 \mathrm{x}+0.323$ & 0.981 \\
\hline & 4 & $\mathrm{y}=0.562 \mathrm{x}^{2}-0.707 \mathrm{x}+0.331$ & 0.917 \\
\hline & 6 & $\mathrm{y}=0.284 \mathrm{x}^{2}-0.303 \mathrm{x}+0.226$ & 0.931 \\
\hline \multirow{3}{*}{$\mathbf{5 5}^{\circ} \mathbf{C}$} & 2 & $\mathrm{y}=0.078 \mathrm{x}^{2}+0.249 \mathrm{x}+0.041$ & 0.986 \\
\hline & 4 & $\mathrm{y}=0.00007 \mathrm{x}^{2}-0.011 \mathrm{x}+0.594$ & 0.957 \\
\hline & 6 & $\mathrm{y}=0.586 \mathrm{x}^{2}-0.858 \mathrm{x}+0.340$ & 0.937 \\
\hline & 8 & $\mathrm{y}=0.194 \mathrm{x}^{2}-0.125 \mathrm{x}+0.12$ & 0.924 \\
\hline & 6 & $\mathrm{y}=0.151 \mathrm{x}^{2}-0.02 \mathrm{x}+0.083$ & 0.987 \\
\hline
\end{tabular}

Table.2 Moisture diffusivity values for dried bael fruit pulp

\begin{tabular}{|c|c|l|l|l|}
\hline Treatment & $\begin{array}{c}\text { Drying } \\
\text { temperature }\left({ }^{\circ} \mathbf{C}\right)\end{array}$ & Regression equation & Diffusivity & $\mathbf{R}^{\mathbf{2}}$ \\
\hline & 2 & $\mathrm{y}=-0.009 \mathrm{x}-0.137$ & $3.65 \times 10^{-9}$ & $\mathbf{0 . 9 9 2}$ \\
\hline & 4 & $\mathrm{y}=-0.012 \mathrm{x}+0.188$ & $1.94 \times 10^{-8}$ & $\mathbf{0 . 9 7 8}$ \\
\hline $\mathbf{6 5}^{\circ} \mathbf{C}$ & 6 & $\mathrm{y}=-0.010 \mathrm{x}+0.352$ & $3.65 \times 10^{-8}$ & $\mathbf{0 . 8 5 7}$ \\
\hline & 8 & $\mathrm{y}=-0.009 \mathrm{x}+0.372$ & $5.84 \times 10^{-8}$ & $\mathbf{0 . 8 8 3}$ \\
\hline & 2 & $\mathrm{y}=-0.005 \mathrm{x}-0.253$ & $2.02 \times 10^{-9}$ & $\mathbf{0 . 9 8 7}$ \\
\hline & 4 & $\mathrm{y}=-0.007 \mathrm{x}+0.113$ & $1.13 \times 10^{-8}$ & $\mathbf{0 . 9 4 2}$ \\
\hline & 6 & $\mathrm{y}=-0.007 \mathrm{x}+0.236$ & $2.55 \times 10^{-8}$ & $\mathbf{0 . 9 2 7}$ \\
\hline $\mathbf{6 0}^{\circ} \mathbf{C}$ & 8 & $\mathrm{y}=-0.006 \mathrm{x}+0.173$ & $3.89 \times 10^{-8}$ & $\mathbf{0 . 9 3 1}$ \\
\hline & 2 & $\mathrm{y}=-0.003 \mathrm{x}-0.136$ & $1.21 \times 10^{-9}$ & $\mathbf{0 . 9 3 6}$ \\
\hline & 4 & $\mathrm{y}=-0.004 \mathrm{x}+0.013$ & $6.49 \times 10^{-9}$ & $\mathbf{0 . 9 1 2}$ \\
\hline & 6 & $\mathrm{y}=-0.004 \mathrm{x}+0.080$ & $1.46 \times 10^{-8}$ & $\mathbf{0 . 9 3 8}$ \\
\hline $\mathbf{5 5}^{\circ} \mathbf{C}$ & $\mathbf{8}$ & $\mathbf{y}=-\mathbf{0 . 0 0 4} \mathbf{x}+\mathbf{0 . 0 9 3}$ & $\mathbf{2 . 5 9} \times \mathbf{1 0}^{-8}$ & $\mathbf{0 . 9 9 4}$ \\
\hline
\end{tabular}


Fig.1 Flow chart for development of bael fruit pulp powder

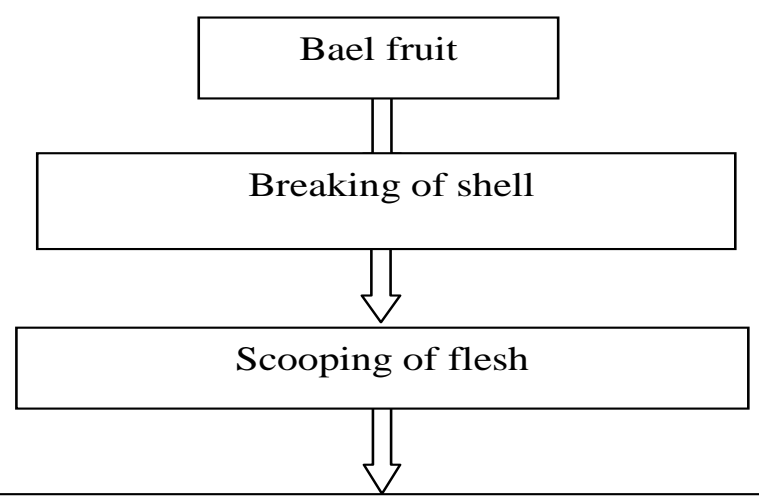

Extraction of pulp by adding water to flesh (1:1) adjusting pH 4.3, Heating at $80^{\circ} \mathrm{C}$ for $1 \mathrm{~min}$ and passing through 20 mesh sieve

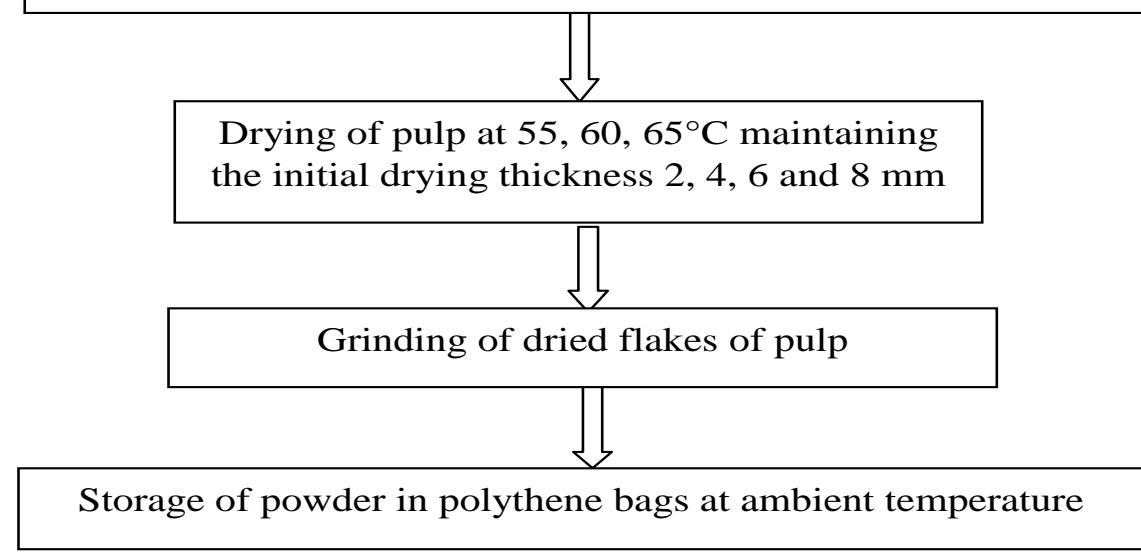

Fig.2 Drying curves of bael fruit pulp obtained for $2 \mathrm{~mm}$ thickness at different air Temperature

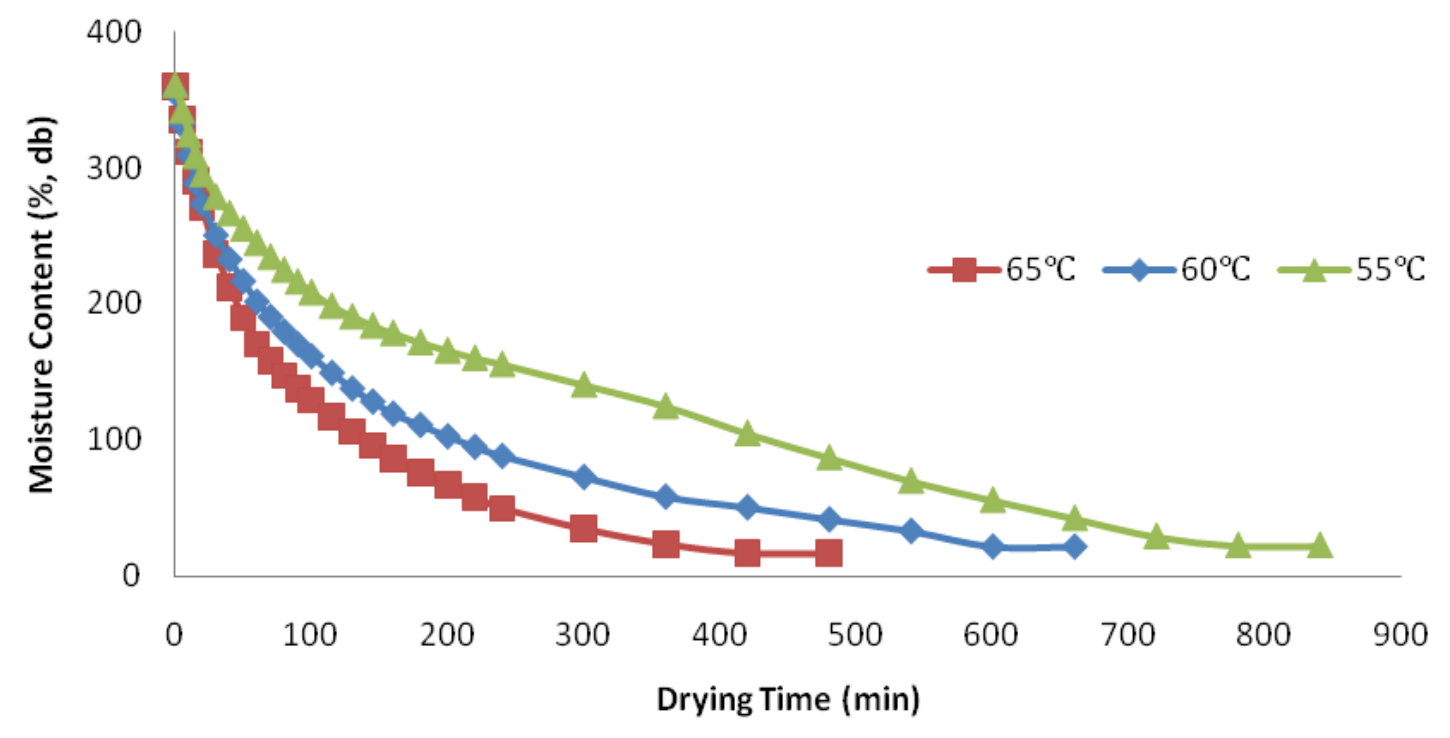


Fig.3 Drying curves of bael fruit pulp obtained for $4 \mathrm{~mm}$ thickness at different air Temperature

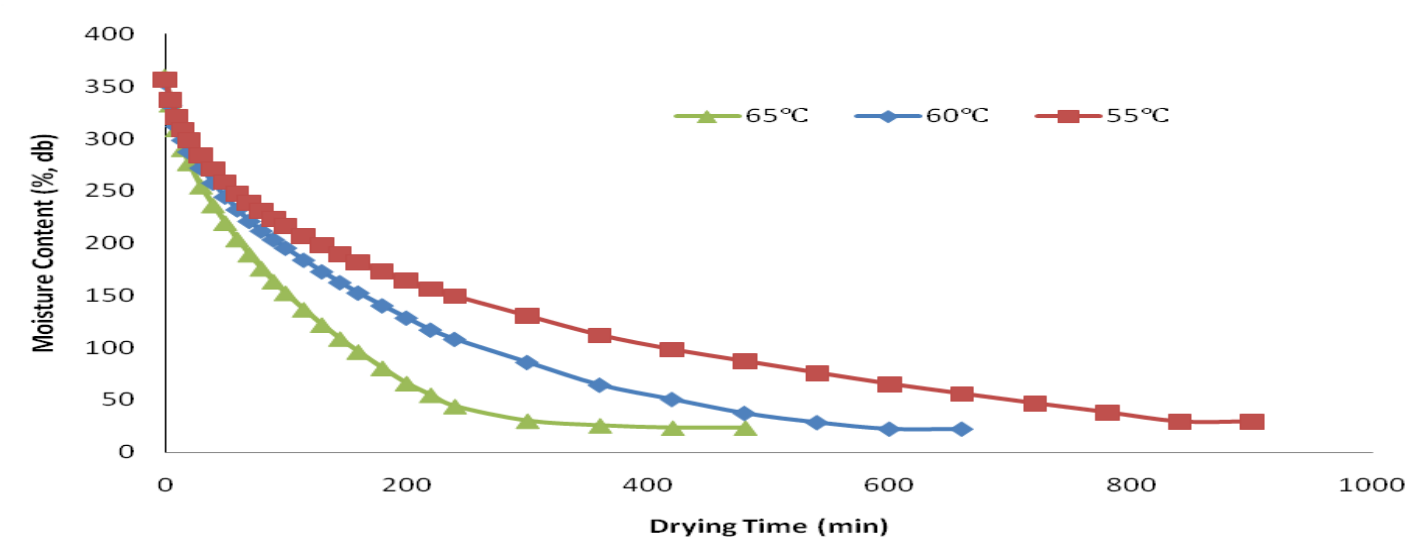

Fig.4 Drying curves of bael fruit pulp obtained for $6 \mathrm{~mm}$ thickness at different air Temperature

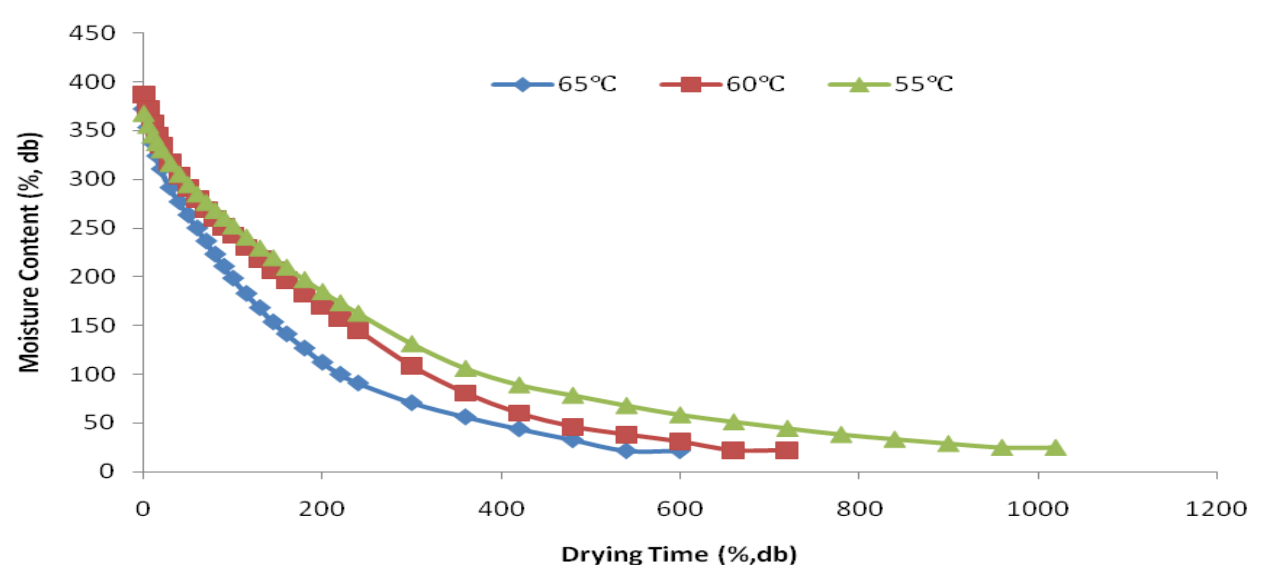

Fig.5 Drying curves of bael fruit pulp obtained for 8mm thickness at different air Temperature

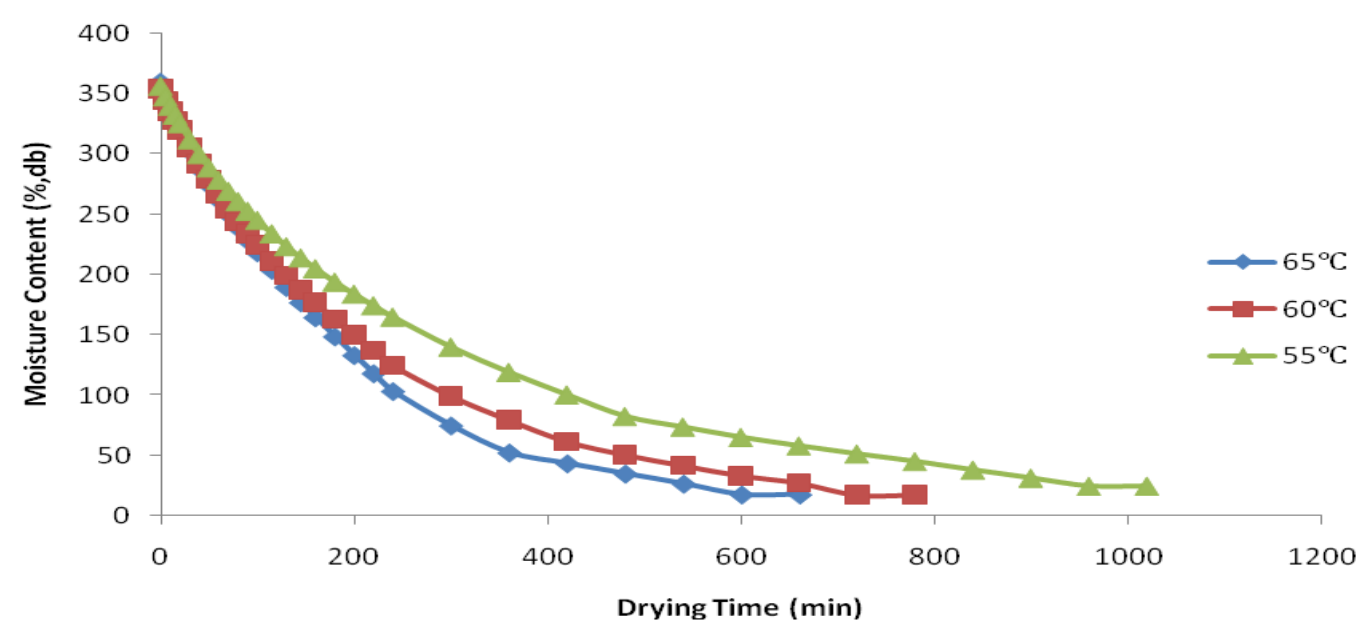


Fig.6 Drying rate curves of bael fruit pulp obtained for $2 \mathrm{~mm}$ thickness at different air Temperature

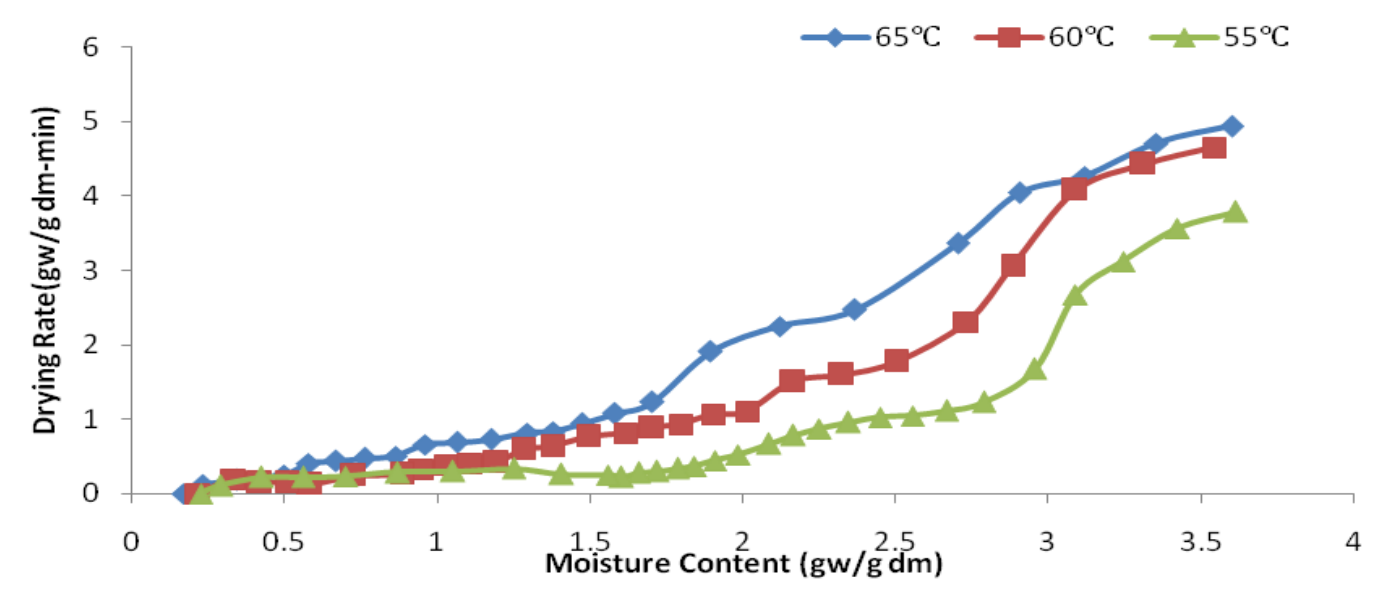

Fig.7 Drying rate curves of bael fruit pulp obtained for $4 \mathrm{~mm}$ thickness at different air Temperature

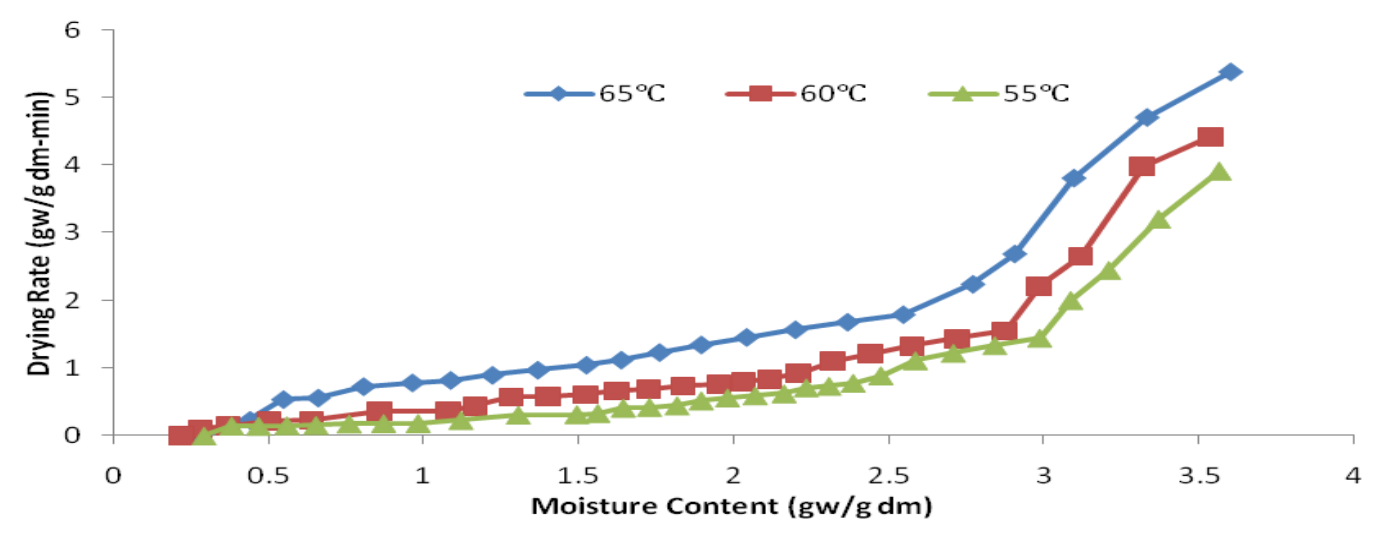

Fig.8 Drying rate curves of bael fruit pulp obtained for $6 \mathrm{~mm}$ thickness at different air Temperature

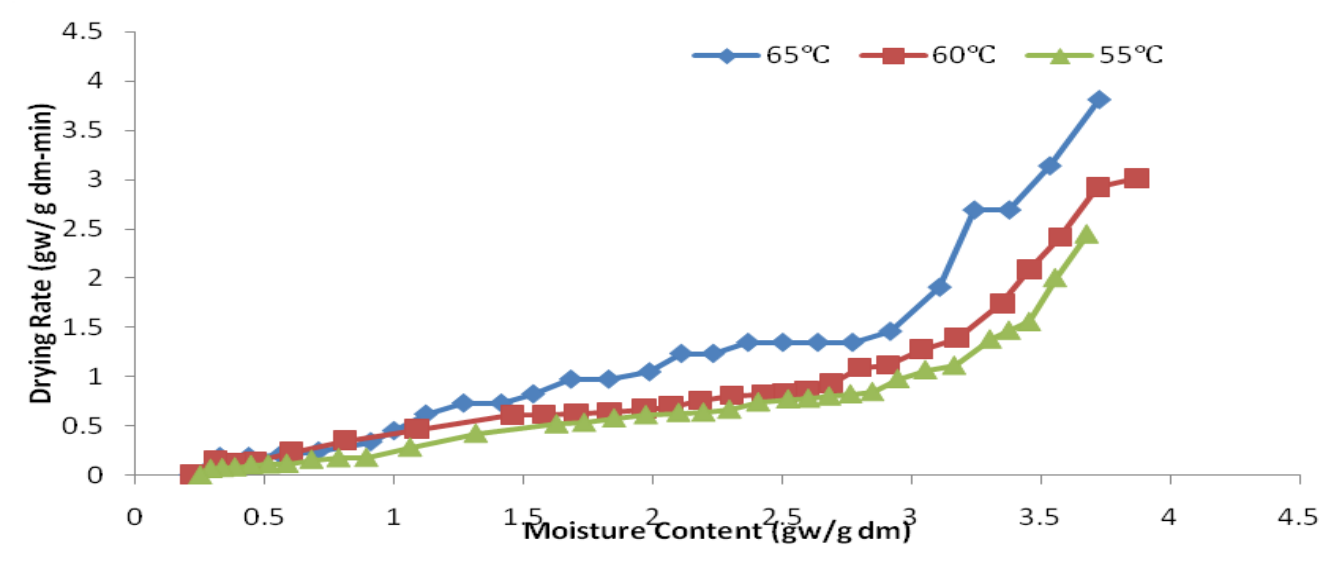


Fig.9 Drying rate curves of bael fruit pulp obtained for $8 \mathrm{~mm}$ thickness at different air Temperature

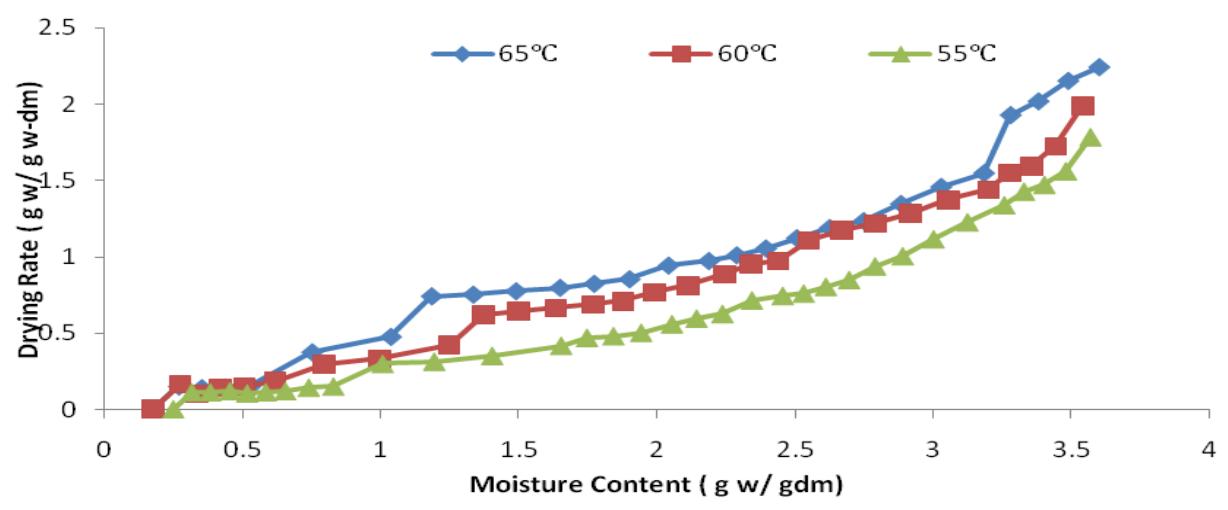

Fig.10 ln MR verses drying time for bael fruit pulp for $2 \mathrm{~mm}$ thickness at different air temperature

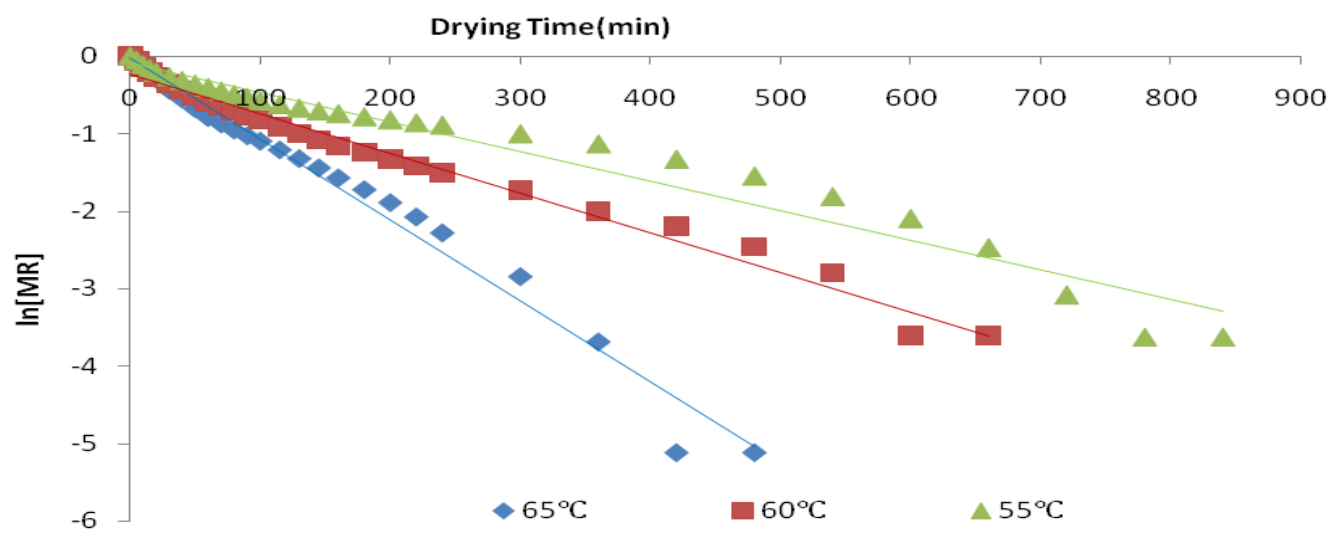

Fig.11 ln MR verses drying time for bael fruit pulp for $4 \mathrm{~mm}$ thickness at different air temperature

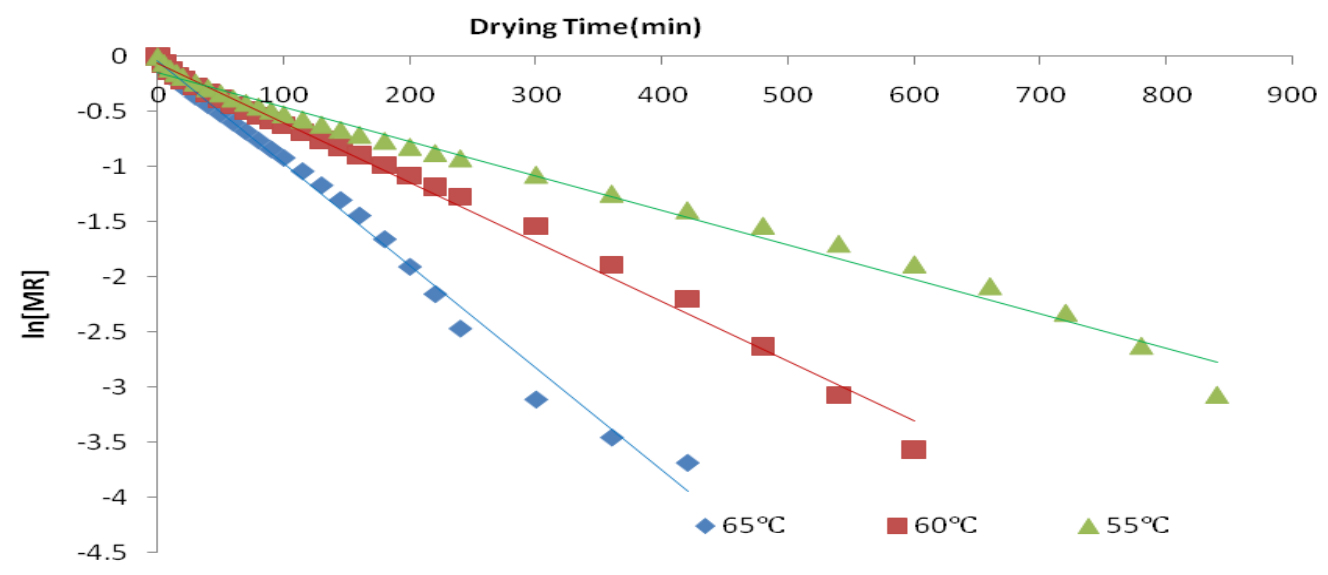


Fig.12 ln MR verses drying time for bael fruit pulp for $6 \mathrm{~mm}$ thickness at different air temperature

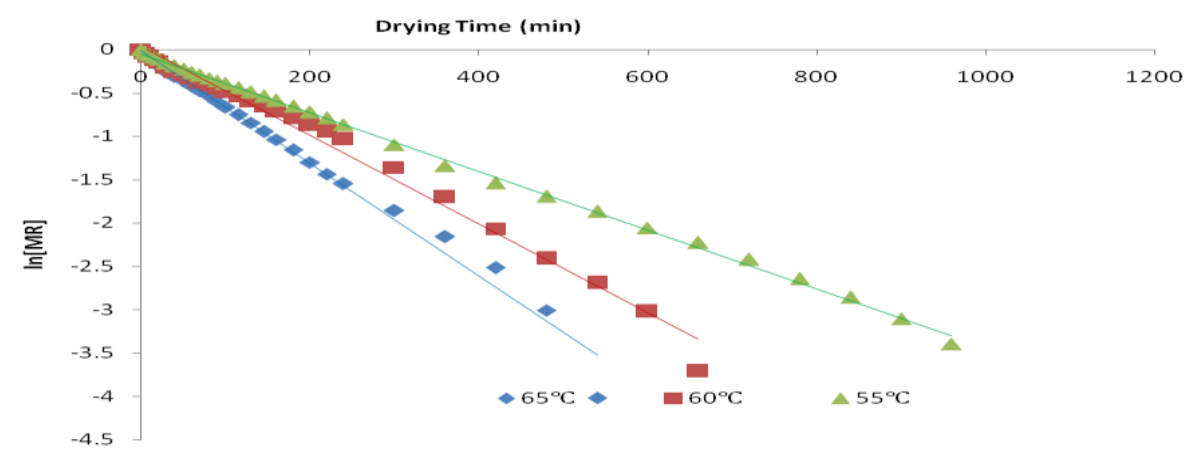

Fig.13 ln MR verses drying time for bael fruit pulp for $8 \mathrm{~mm}$ thickness at different air temperature

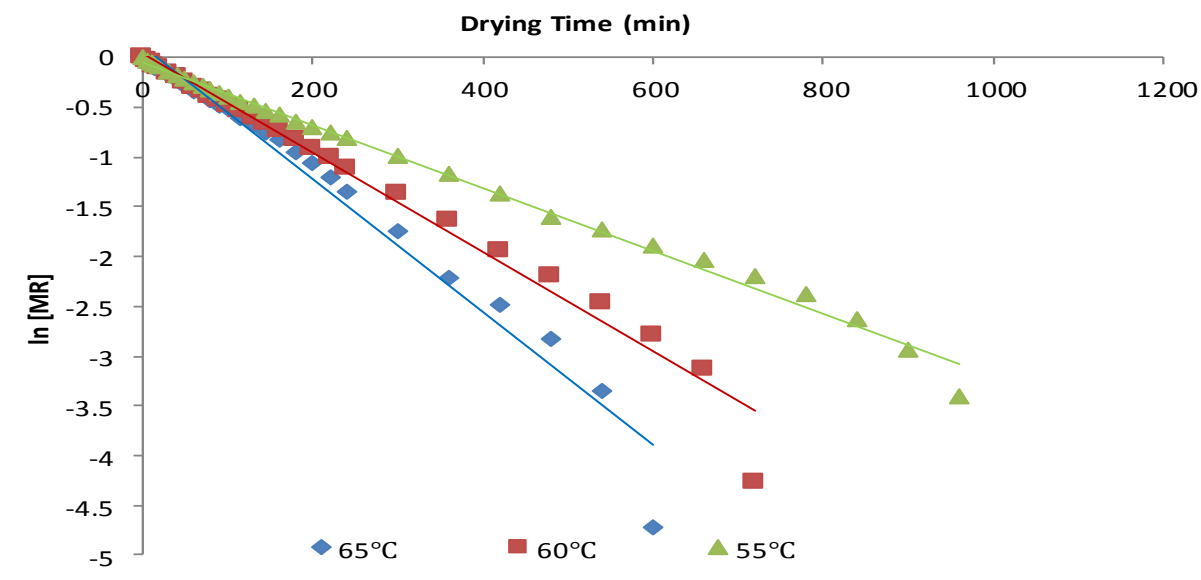

Plate.1 Dried bael fruit pulp powder

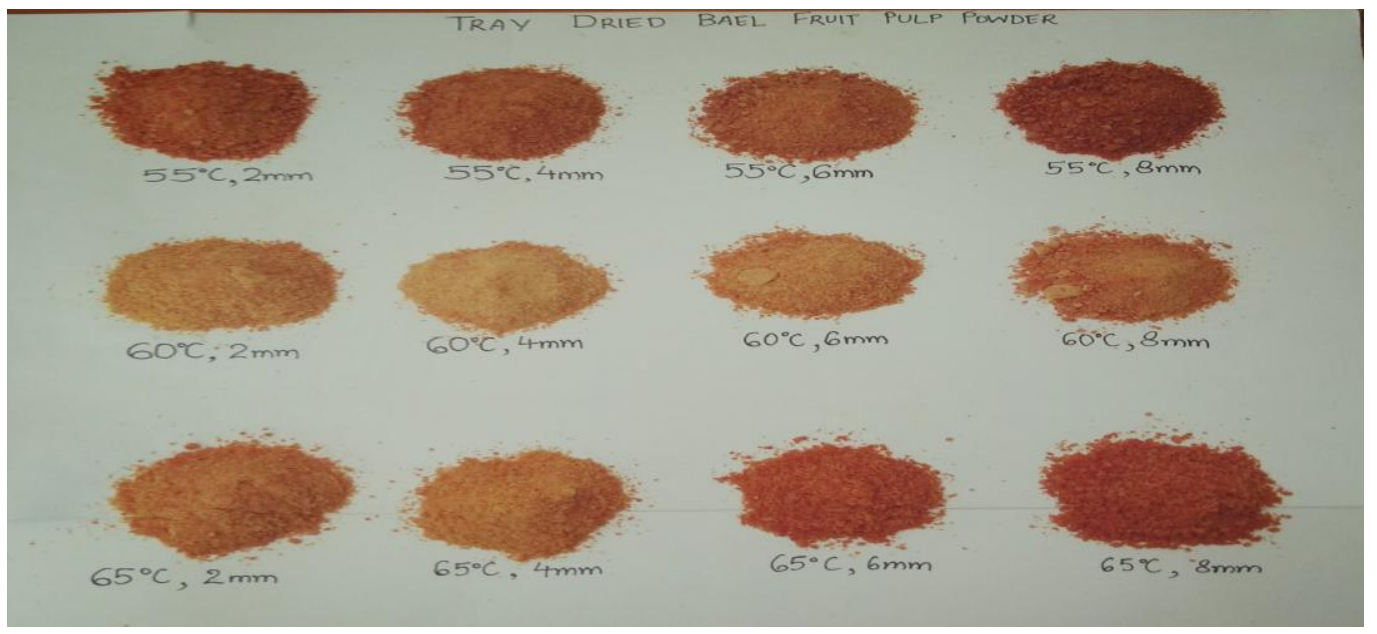


For bael fruit pulp the moisture diffusivity increased from $1.21 \times 10^{-9}$ to $3.6 \times 10^{-9} \mathrm{~m}^{2} / \mathrm{s}$ as the drying air temperature increased from 55 to $65^{\circ} \mathrm{C}$ for $2 \mathrm{~mm}$ thickness of layer. moisture diffusivity increased from $6.49 \times 10^{-9}$ to $1.94 \times 10^{-8} \mathrm{~m}^{2} / \mathrm{s}$ as the drying air temperature increased from 55 to $65^{\circ} \mathrm{C}$ for $4 \mathrm{~mm}$ thickness of layer and moisture diffusivity increased from $1.46 \times 10^{-8}$ to $3.65 \times 10^{-8}$ for $6 \mathrm{~mm}$ and for $8 \mathrm{~mm}$. It increased from $2.59 \times 10^{-8}$ to 5.84 $\mathrm{x} 10^{-8}$ at temperature increased from 55 to $65^{\circ} \mathrm{C}$.

\section{Tray dried bael fruit pulp powder}

The initial moisture content of sample was in the range of 74.49 per cent to 77.10 per cent (wb). Final moisture content ranges in between 6.86 - 9.96 per cent (wb) for dried bael fruit pulp. Average drying time was found to be more at temperature $55^{\circ} \mathrm{C}$ and $8 \mathrm{~mm}$ thickness of about $1020 \mathrm{~min}$, less time was found at temperature $65^{\circ} \mathrm{C}$ and $2 \mathrm{~mm}$ thickness of about $480 \mathrm{~min}$. Moisture reduction per hour was higher at initial stages and then started to decrease with drying time. It was observed that drying occurred completely in falling rate period and no constant rate period was observed at all drying temperatures. The moisture diffusivity varied in the range of $1.21 \times 10^{-9} \mathrm{~m}^{2} / \mathrm{s}$ to 5.84 $\mathrm{x} 10^{-8} \mathrm{~m}^{2} / \mathrm{s}$ during drying.

Among the range of variables taken for the convective drying of bael fruit pulp sample, sample which has thickness of $2 \mathrm{~mm}$ at $60^{\circ} \mathrm{C}$ air temperature was found optimum in terms of response.

\section{References}

Akpinar, E.K., Bicer, Y. and Yildiz, C. 2003. Thin layer drying of red pepper. Journal of Food Engineering, 59: 99104.

Anonymous. 2012. The Earth of India. http://theindianvegan.blogspot.in/2012/10/allabout-bael.html.

Anonymous. 2015. National Horticulture Board.

http://apeda.in/agriexchange/India\%2 OProduction/India_Productions.aspx? cat $=$ fruit $\&$ scode $=1041$.

Anonymous. 2017. Gyanunlimited. http://www.gyanunlimited.com/health/ 10-wonder-benefits-and-uses-of-baelaegle-marmelos/11321/.

AOAC. 2000. Official Methods of Analysis. $14^{\text {th }}$ Ed. Edited by Sidney Williums. Published by the Association of Official Analysis Chemists, Inc. Arlinton, Virginia, 22209, USA.

Bag, S.K., Srivastav, P.P. and Mishra, H.N. 2011. Optimization of process parameters for foaming of bael (Aegle marmelos L.) fruit pulp. Food Bioprocess Technology, 4: 14501458.

Baliga, M.S., Bhat, H.P., Joseph, N. and Fazal, F. 2011. Phytochemistry and medicinal uses of the bael fruit (Aegle marmelos Correa). A concise review. Food Research International, 44: 1768-1775.

Brooker, D.B., Bakker, F.W. and Hall, C.W. 1974. Drying and Storage of Grains and Oilseeds. The AVI Publishing Company, Inc. Westport, Connecticut, 56-71.

Chundawat, B.S. 1990. Arid Fruit Culture. Oxford \& IBH Publishing Co. Pvt. Ltd. New Delhi, India.

Doymaz, I. 2004. Drying kinetics of white mulberry. Journal of Food Engineering, 61: 341-346.

Doymaz, I. and Ismail, O. 2010. Drying and rehydration behaviours of green bell peppers. Food Science Biotechnology, 19: 1449-1455.

Doymaz, I. and Ismail, O. 2011. Drying characteristics of sweet cherry. Food Bioproducts Processing, 89: 31-38. 
Fenton, G.A. and Kennedy, M.J. 1998. Rapid dry weight determination of kiwifruit pomace and apple pomace using infrared drying technique. New Zealand Journal of Crop and Horticultural Science, 26: 35-38.

Goyal, R.K., Kingsly, A.R.P., Manikanthan, M.R. and Ilyas, S.M. 2007. Mathematical modelling of thin layer drying kinetics of plum in a tunnel dryer. Journal of Food Engineering, 79:176-180.

Jain, S.K., Verma, R.C., Murdia, L.K., Jain, H.K. and Sharma, G.P. 2011. Optimization of process parameters for osmotic dehydration of papaya cubes. Journal of Food Science and Technology, 48: 211-217.

John, L. and Stevenson, V. 1979. The complete book of fruit. Angus and Robertson Publishers Sydney.

Julia, F.M. and Miami, F.L. 1987. Bael fruit. https://hort.Purdue.edu/new crop/morton/bael_fruit.html.

Kadam, D.M. and Balasubramanian, S. 2011. Foam mat drying of tomato juice. Journal of Food Processing and Preservation, 35: 488-495.

Kaur, H.P., Garg, S.N., Sashidhara, K.V. and Yadav, A. 2006. Chemical Composition of the Essential Oil of the Twigs and Leaves of Aegle marmelos. Journal of Essential Oil Research, 18: 288-289.

Kaur, A. and Kalia, M. 2017. Physico Chemical Analysis of Bael (Aegle Marmelos) Fruit Pulp, Seed and Pericarp. Chemical Science Review and Letters, 6: 1213-1218.

Kaushik, R.A., Yamdagni, R., Sharma, J.R. and Kenghe, R.N. 2008. Changes in quality parameters during processing and storage of Bael fruit processing for value addition and employment generation. Food Pack Company, 2: 10- 12 .
Kumar, N., Sarkar, B.C. and Sharma, H.K. 2011. Effect of air velocity on kinetics of thin layer carrot pomace drying. Journal of Food Science and Technology International, 17: 417.

Kundu, S.K., Bhattacharjee, S. and Pal, K. 2014. Pharmacological Properties of AegleMarmelos: A Mini Review. PharmaTutor, 2: 63-67.

Maity, P., Hansda, D., Bandyopadhyay, U. and Mishra, D.K. 2009. Biological activities of crude extracts and chemical constituents of Bael, Aegle marmelos (L.) Corr. Indian Journal of Experimental Biology,47: 849-861.

Maskan, A., Kaya, S. and Maskan, M. 2002. Hot air and sun drying of grape leather (pestil). Journal of Food Engineering, 54: 81-88.

Meisami-asl, E. and Rafiee, S. 2009. Mathematical Modeling of Kinetics of Thin-layer Drying of Apple (var. Golab). Agricultural Engineering International: the CIGR Ejournal, XI: 1185.

Prajapat, R.P., Gupta, V., Soni, B., Choudhary, D., Verma, R. and Bhandari, A. 2012. Extraction and Isolation of Marmelosin from Aegle Marmelos, Synthesis and Evaluation of Their Derivative as Antidiabetic Agent. Der Pharmacia Lettre, 4: 1085-1092.

Ramaswamy, H.S. and Nieuwveenhuijzen, N.H. 2002. Evaluation and modelling of two stage osmo convective drying of apple slices. Drying Technology, 20: 651-667.

Roy, S.K. and Singh, R.N. 1979. Studies on utilization of Bael fruit for processingII: Extraction of Bael fruit pulp. Indian Food Packer, 33: 5-9.

Shankhla, A., Sharma, S., Sharma, N. 2009. Hypoglycemic effect of Bael patra (Aegle marmelos) in NIDDM patients. Journal of Dairying Food and Home 
science, 28: 3-4.

Sharma, P.C., Bhatia, V., Bansal, N. and Sharma, A. 2007. A review on Bael Tree, Natural Product Radiance, 6: 171-178.

Singh, H. 2001. Osmotic dehydration of carrot shreds for gazraila preparation. Journal of Food Science and Technology, 38: 152-154.

Singh, A.K. and Nath, N. 2004. Development and evaluation of whey protein enriched bael (Aegle Marmelos) fruit beverage. Journal Food Science Technology, 41: 432-436.

Singh, A., Sharma, H.K., Kumar, S., Upadhyay, A. and Mishra, K.P. 2013. Comparative effect of crude and commercial enzyme on the juice recovery from bael fruit (Aegle marmelos Correa) using principal component analysis. International Journal of Food Science, 1-8.

Venkatesan, D., Karrunakarn, C.M., Selva, S.K. and Palani, P.T.S. 2009. Identification of Phytochemical Constituents of Aegle marmelos Responsible for Antimicrobial Activity against Selected Pathogenic Organisms. Ethno botanical Leaflets,
13: 1362-1372.

Vergara, F., Amezaga, E., Barcenas, M.E. and Welti, J. 1997. Analysis of the drying processes of osmotically dehydrated apple using the characteristic curve model. Drying Technology, 15: 949963.

Wang, Z., Junhong, S., Xiaojun, L., Chen, F., Zhao, G., Jihong, W. and Xiaosong, H. 2007. Mathematical modeling on hot air drying of thin layer apple pomace. Food Research International, 40: 39-46.

Wankhade, P.K., Sapkal, R.S. and Sapkal, V. S. 2013. Dryingcharacteristics of okra slices on drying in hot air dryer.Procedia Engineering, 51:371 374.

Wijewardana, R.M.N.A., Nawarathne, S.B., Wickramasinghe, I., Gunawardane, C.R., Wasala, W.M.C.B. and Thilakarathne, B.M.K.S. 2015. Retention of physicochemical and antioxidant properties of dehydrated bael (Aegle marmelos) and palmyra (Borassus flabellifer) fruit powders. Procedia Food Science, 6: 170-175.

\section{How to cite this article:}

Ankita Sharma, P. S. Champawat, Surbhi Suman, Kusum Meghwal and Neha Prajapat. 2020. Drying Characteristics of Bael Fruit (Aegle Marmelos) Pulp in Mechanical Tray Dryer. Int.J.Curr.Microbiol.App.Sci. 9(08): 922-935. doi: https://doi.org/10.20546/ijcmas.2020.908.100 